\title{
PENILAIAN INDEKS KOTA RAMAH AIR UNTUK KOTA BOGOR UNTUK PENYUSUNAN STRATEGI KEBIJAKAN
}

\section{Muhammad Ramdhan ${ }^{1,2}$, Hadi Susilo $A^{3}$., Yuli Suharnoto ${ }^{4}$, Suria Darma T. ${ }^{5}$}

1Peneliti muda pada Pusat Riset Kelautan, BRSDM - KKP, 2Mahasiswa S3 Program Studi

Pengelolaan Sumberdaya Alam dan Lingkungan-IPB, ${ }^{3}$ Fakultas Pertanian, Departemen

Arsitektur Lanskap - IPB, ${ }^{4}$ Fakultas Teknik Pertanian, Departemen Teknik Sipil dan Lingkungan - IPB, ${ }^{5}$ Fakultas Pertanian, Departemen Ilmu Tanah dan Sumberdaya Lahan - IPB

Jln. Pasir Putih 1 Ancol Jakarta; Telp/fax : +62 2164711583

Email : m.ramdhan@kkp.go.id

\section{RINGKASAN}

Kota Bogor memiliki permasalahan klise suatu kota yang sedang berkembang yaitu banjir disaat musim penghujan dan kesulitan air bersih pada musim kemarau panjang. Dengan curah hujan rata-rata bulanan sebesar 279,80 mm, Kota Bogor memiliki potensi sumber daya air yang sangat besar. Kota ini memiliki total area $118,5 \mathrm{~km}^{2}$ dan populasi 1.013.019 orang. Perkembangan kota dari waktu ke waktu membutuhkan sistem manajemen sumber daya air yang mempertimbangkan faktor-faktor keberlanjutan, penerapan konsep Kota Ramah Air diharapkan mampu untuk menciptakan suatu pengeloaan sumberdaya air permukaan secara berkelanjutan di Kota Bogor. Tujuan penelitian ini adalah untuk mendapatkan kondisi eksisting kuantitas dan kualitas sumberdaya air permukaan di Kota Bogor, kemudian mencari tolok ukur penilaian indeks menuju kota ramah air dari responden pengguna sumber air permukaan di Kota Bogor, selanjutnya adalah menyusun rekomendasi strategi pengelolaan sumberdaya air permukaan yang berkelanjutan untuk Kota Bogor menggunakan konsep kota ramah air sebagai patokannya.

Kata Kunci : Air Perkotaan, Kota Bogor, Indeks Kota Ramah Air, Struktural Equation Model

\section{PERNYATAAN KUNCI}

- Kota Bogor memiliki sumberdaya air permukaan yang besar. Hasil simulasi perhitungan potensi air limpasan hujan di kota Bogor pada tahun 2019 sebesar 699.203.293 $\mathrm{m}^{3} /$ tahun.
- Terjadi penurunan kualitas sumberdaya air permukaan yang masuk ke Kota Bogor dilihat dari nilai WQI inlet dan outlet di dua sungai utamanya, yaitu : Sungai Ciliwung dan Sungai Cisadane.

- Indeks kota ramah air di Kota Bogor secara keseluruhan adalah 2,74. Nilai indeks tertinggi berada pada tujuan 6 
yaitu ruang kota yang berkualitas. Dan terendah berada pada tujuan 5 yaitu perbaikan kesehatan lingkungan, lebih spesifik lagi pada kualitas pada aliran permukaan.

\section{REKOMENDASI KEBIJAKAN}

Strategi untuk menuju kota ramah air di Kota Bogor dapat dilakukan melalui rencana tata ruang melibatkan aktor pentabelix yang terdiri dari Akademisi, Pengusaha, Pemerintah, Komunitas dan Media. Penyusunan rencana harus memperhatikan 7 tujuan kota ramah air, yaitu menciptakan pemerintahan yang baik, meningkatkan modal sosial, menciptakan kesempatan yang sama untuk mengakses air, adanya produktifitas dan efisiensi sumberdaya air, memelihara kesehatan lingkungan, menciptakan ruang kota berkualitas dan membangun infrastruktur yang adaptif di Kota Bogor.

\section{PENDAHULUAN}

Air adalah faktor kunci untuk masa depan pembangunan berkelanjutan dari masyarakat dan ekonomi Indonesia (Hadimuljono 2016). Sebagai negara tropis, kota-kota di Indonesia diberkahi dengan sumberdaya air yang melimpah. Meskipun demikian, sebagai negara berkembang, kotakota di Indonesia mengalami ancaman kehilangan sumberdaya airnya. Hal ini diakibatkan oleh pertambahan penduduk

dan proses pembangunan yang kurang terencana dengan baik.

Konsep kota ramah air hadir dengan mengintegrasikan air pada perencanaan kota. Konsep ini memfasilitasi kota agar lebih nyaman sebagai tempat tinggal, meningkatkan keanekaragaman hayati, memberikan peningkatan ruang terbuka biru dan ruang terbuka hijau,saluran air yang sehat dan komunitas yang saling terhubung. Upaya yang dilakukan adalah dengan pengelolaan siklus air perkotaan secara terpadu. Yaitu perlindungan terhadap jalurjalur air, pengurangan resiko bahaya banjir, menciptakan lebih banyak ruang publik, pemanenan air hujan, daur ulang air dan penggunaan air yang sesuai peruntukannya (Brown et al. 2016)

Pengetahuan tentang kondisi terkini pengelolaan sumberdaya air di perkotaan diperlukan oleh pengambil keputusan dan para pemangku kepentingan lain. Indeks kota ramah air dikembangkan untuk mendukung para pengambil keputusan di tingkat kota dalam merencanakan kota ramah air. Indeks ini juga dapat meningkatkan partisipasi pemangku kepentingan lainnya untuk mengawasi dan mendukung pelaksanaan rencana kota ramah air. 


\section{SITUASI TERKINI}

Kota Bogor, Provinsi Jawa Barat. Secara geografis Kota Bogor terletak pada rentang koordinat $106^{\circ} 43^{\prime} 59.2^{\prime \prime}$ - 106 50' 54.8” BT; $6^{\circ} 30^{\prime} 38.6^{\prime \prime}$ - 6 40’ 48.5” LS (Gambar 3.1), Kota Bogor dikelilingi oleh wilayah Kabupaten Bogor. Kota Bogor mempunyai rata-rata ketinggian minimum $190 \mathrm{~m}$ dan maksimum $330 \mathrm{~m}$ dari permukaan laut. Kondisi iklim di Kota Bogor selama tahun 2016: suhu rata-rata bulanan maksimal adalah $31,8{ }^{\circ} \mathrm{C}$ dan minimal $23,3{ }^{\circ} \mathrm{C}$, kelembaban udara 93,6 persen, curah hujan rata-rata bulanan sekitar 365,6 - 402,9 mm dengan curah hujan terbesar terjadi pada bulan September 2016 (BPS 2017).

Kota Bogor dikelilingi oleh wilayah Kabupaten Bogor dengan batas-batas sebagai berikut:

a. Sebelah Utara berbatasan dengan Kecamatan Kemang, Bojong Gede dan Sukaraja Kabupaten Bogor.

b. Sebelah Timur berbatasan dengan Kecamatan Sukaraja dan Ciawi Kabupaten Bogor.

c. Sebelah Barat berbatasan dengan Kecamatan Darmaga dan Ciomas Kabupaten Bogor.

d. Sebelah Selatan berbatasan dengan Kecamatan Cijeruk dan Caringin Kabupaten Bogor.Kota Bogor memiliki total luas wilayah $118.5 \mathrm{Km}^{2}$. Wilayah tersebut dibagi menjadi 6 kecamatan, 68 kelurahan, 780 Rukun Warga dan 3479 Rukun Tetangga (BPS. 2014). Data sebaran penduduk di kota berdasarkan hasil sensus 2010 berjumlah 1.013.019 Jiwa. Kecamatan Bogor Barat memiliki jumlah penduduk paling banyak yaitu 224.963 jiwa, Bogor Timur memiliki jumlah penduduk terkecil, yaitu 100.517 Jiwa. Sedangkan kepadatan penduduk tertinggi terdapat di Bogor Tengah dengan jumlah $12.758 \mathrm{Jiwa} / \mathrm{Km}^{2}$.

Terdapat dua sungai utama yang melewati Kota Bogor. Pertama adalah sungai Ciliwung, Sungai Ciliwung melewati Kota Bogor memiliki panjang ruas $14,403 \mathrm{Km}$, sungai ini melewati 4 Kecamatan di Kota Bogor, yaitu Kec. Bogor Timur, Kec. Bogor Tengah, Kec. Bogor Utara dan Kec. Tanah Sareal. Sungai kedua adalah Sungai Cisadane, sungai ini melalui 3 kecamatan di Kota Bogor, yaitu Kec. Bogor Selatan, Kec. Bogor Tengah, dan Kec. Bogor Barat dengan total panjang 21,352 Km.

Pada Gambar 1. dapat terlihat bahwa Badan Perencanaan Pembangunan Daerah Kota Bogor telah membagi wilayah Kota Bogor kedalam 15 zona drainase. Zona draonase ini disusun berdasarkan sub-DAS aliran sungai. Di bagian timur adalah subDAS sungai Ciliwung dan di bagian barat merupakan sub-DAS sungai Cisadane. 


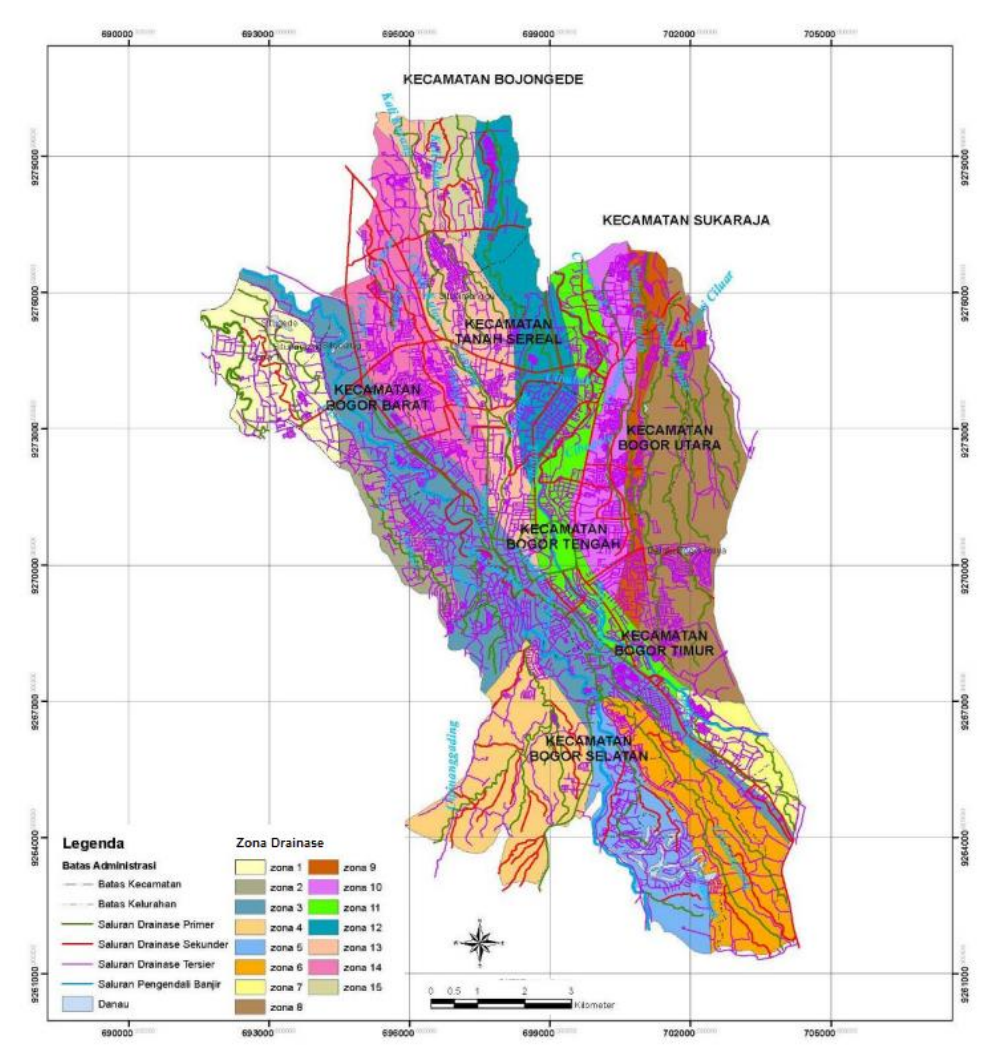

Gambar 1. Peta Lokasi Penelitian - Kota Bogor

\section{METODOLOGI}

Metode WSC Index Chesterfield et al.(2016) diadopsi menjadi metode Indeks Kota Ramah Air. Terdapat 34 indikator yang terbagi dalam 7 tujuan.

Daftar tujuan beserta indikatornya adalah sebagai berikut:

1. Memastikan tata kelola/pemerintahan yang ramah air

1.1 Pengetahuan, keterampilan dan kapasitas organisasi

1.2 Air adalah elemen utama dalam perencanaan tata ruang kota

1.3 Pengaturan dan proses institusional lintas sektor
1.4 Keterlibatan publik, partisipasi dan transparansi

1.5 Kepemimpinan, visi jangka panjang dan komitmen

1.6 Pendanaan sumberdaya air untuk mendapatkan nilai sosial yang luas

1.7 Persamaan representasi dan perspektif

2. Meningkatkan modal sosial

2.1 Literasi air

2.2 Keterhubungan dengan air

2.3 Pembagian Kepemilikan, pengelolaan dan tanggungjawab terhadap aset air

2.4 Kesiapan komunitas dan respon terhadap kejadian ekstrim

2.5 Keterlibatan masyarakat lokal dalam perencanaan air 
3. Pencapaian persamaan dari layanan dasar

3.1 Kesamaan hak akses terhadap persediaan air yang sehat dan aman

3.2 Kesamaan hak akses terhadap sanitasi yang tersedia dan aman

3.3 Kesamaan hak akses terhadap perlindungan banjir

3.4 Kesamaan dan keterjangkauan akses terhadap nilai kenyamanan terkait aset perairan

4. Perbaikan produktifitas dan efesiensi sumber daya

4.1 Akses keuntungan sektor lain akibat layanan terkait air

4.2 Emisi Gas Rumah Kaca yang rendah pada sektor air

4.3 Kebutuhan tempat air minum bagi masyarakat

4.4 Peluang bisnis terkait air

4.5 Memaksimalkan pemulihan sumberdaya

5. Perbaikan kesehatan lingkungan

5.1 Habitat yang sehat dan beragam

5.2 Kualitas dan aliran air permukaan

5.3 Kualitas air tanah dan pengisiannya

5.4 Perlindungan kawasan eksisting yang memiliki nilai ekologi tinggi

6. Memastikan ruang kota yang berkualitas

6.1 Pengaktifan penghubung ruang hijau dan biru perkotaan

6.2 Fungsi elemen perkotaan bagi migitasi dampak pemanasan global

6.3 Liputan vegetasi
7. Promosi infrastruktur yang adaptif

7.1 Keragaman pemenuhan sendiri bagi persediaan air yang tepat guna

7.2 Sistem infrastruktur air yang multifungsi

7.3 Pengendalian yang terintegrasi dan canggih

7.4 Infrastruktur yang tahan terhadap gangguan

7.5 Infrastruktur dan kepemilikan dalam beragam skala

7.6 Perawatan yang memadai

Quisioner disebarkan secara online pada tanggal 20 Mei 2018 sampai 29 Mei 2018, daftar pertanyaan dapat dilihat pada lampiran 5. Kemudian data hasil quisioner akan dianalisis menggunakan analisis faktor konfirmatori (AFK) dengan menggunakan software AMOS agar dapat dilihat hubungan antar indikator dan tujuan menurut responden saat ini.

\section{ANALISIS DAN ALTERNATIF SOLUSI/PENANGANAN}

A. Analisis deskriptifResponden terkumpul pengukuran nilai indeks kota ramah air di Kota Bogor ada 74 (lampiran 6). 62\% diantaranya berkelamin pria dan 38\% wanita. Umur responden terbagi atas 7\% berusia diatas 50 tahun, 31\% berusia antara 17 - 30 tahun, dan $62 \%$ berusia antara 31 - 50 tahun. Pekerjaan responden Hasil nilai indeks Kota Ramah Air untuk Kota Bogor adalah 2,74 (Gambar 2). 


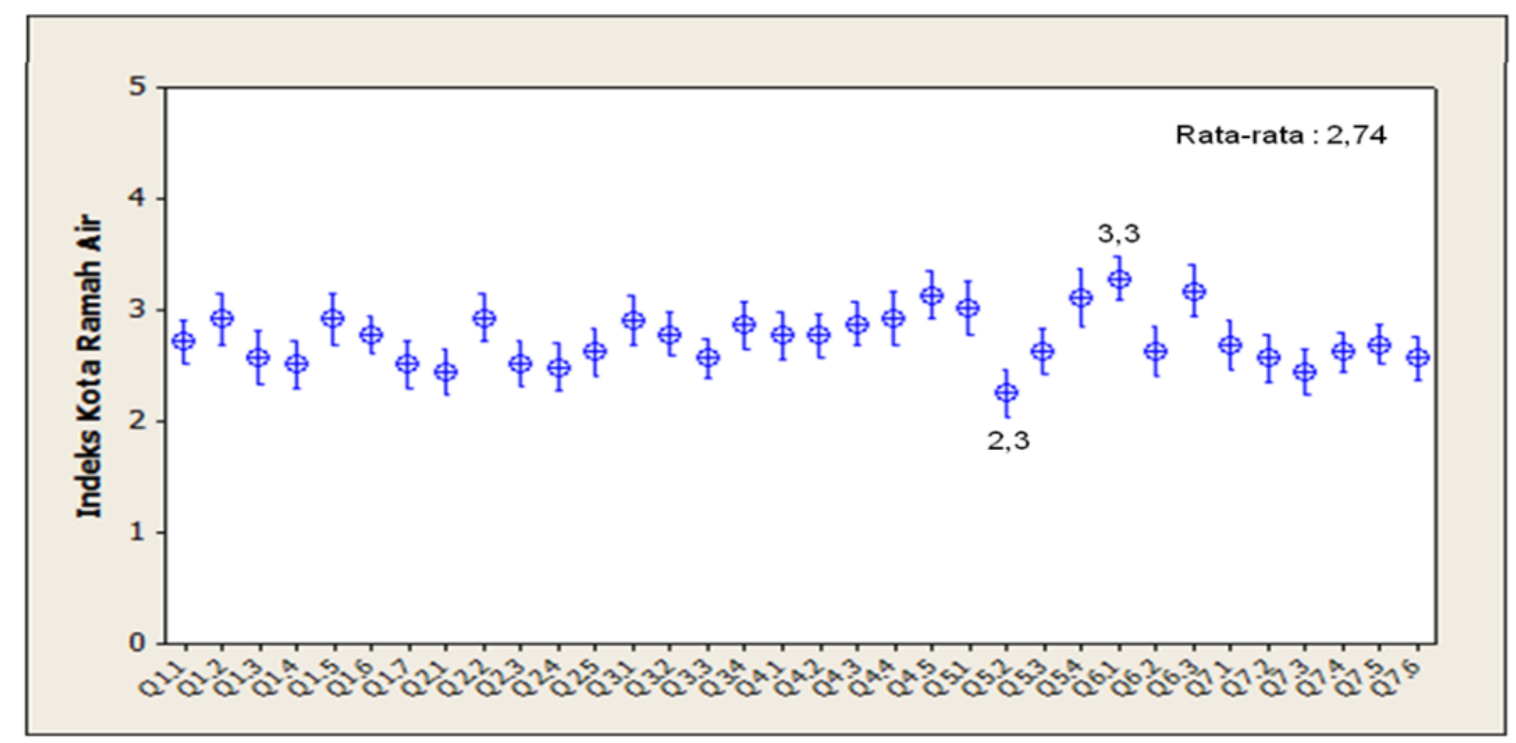

Gambar 2. Indeks Kota Ramah Air untuk Kota Bogor

Nilai terendah diperoleh dari indikator kualitas air permukaan yang ada di kota Bogor yang bernilai 2,30. Sedangkan nilai tertinggi ada pada indikator keterhubungan ruang hijau dan biru perkotaan di Kota Bogor.

Gambar 3. menampilkan hasil indeks per tujuan. Infrastruktur yang adaptif dan peningkatan modal sosial mendapatkan nilai terendah yaitu 2,60. Sedangkan ruang kota yang berkualitas di kota bogor mendapat skor tertinggi yaitu 3.03. Hasil penelitian Alfiasari (2008) menyatakan bahwa komponen modalsosial berupa kepercayaan, jaringansosial, dan norma sosial yang dimiliki masyarakat Kota Bogor dalam menjalinhubungan sosialnya berada

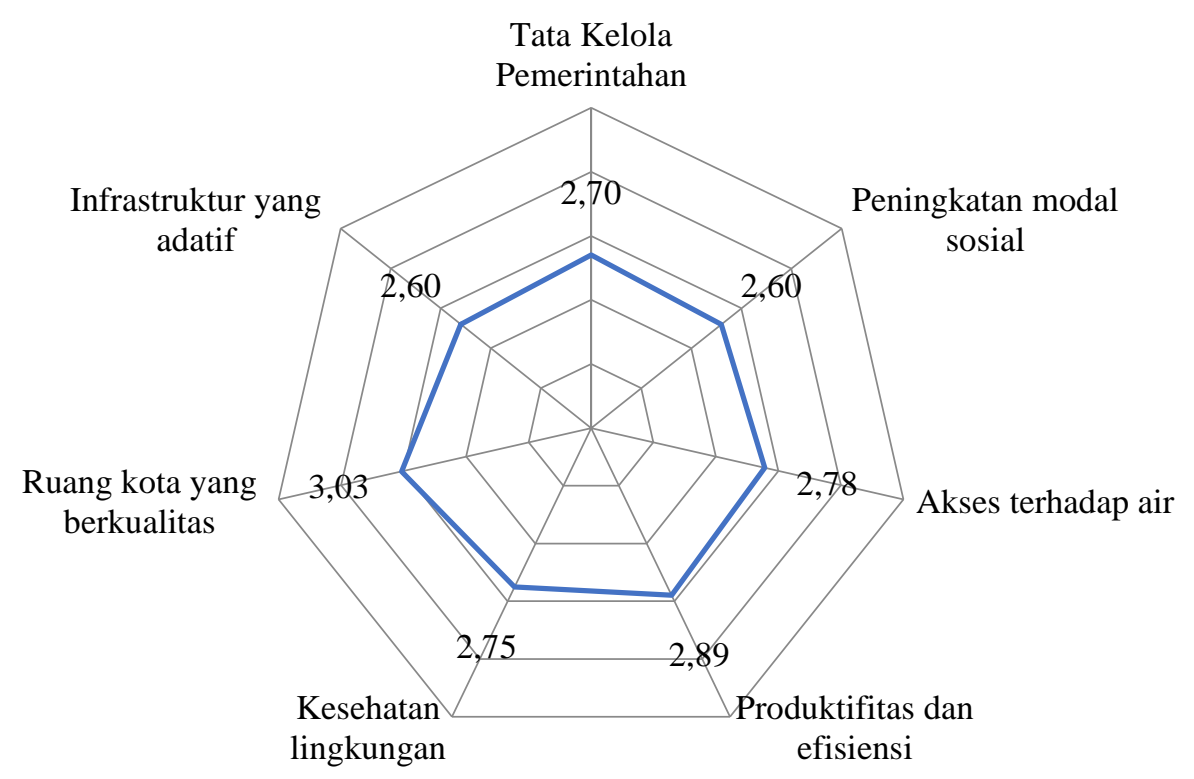

Gambar 3. Nilai Indeks Kota Ramah Air untuk Kota Bogor per tujuan 
dalamkategori sedang.Hal ini untuk menguji atau mengkonfirmasikan mengkonfirmasi hasil indeks diatas secara empiris model pengukuran mengenai modal sosial. Infrastruktur Kota (measurement model) sebuah atau beberapa Bogor mendapat nilai rendah, hal ini diakui konstruk. Model pengukuran atau disebut oleh walikota bogor (Arya 2017) bahwa infrastruktur Kota Bogor belum dalam kondisi baik saat ini, contohnya jalan kurang lebar, kondisi transportasi sudah tidak layak pakai atau kurang ramah lingkungan, jembatannya kurang lebar, arus lalu lintasnya kurang rapi. Ruang kota berkualitas di Kota Bogor mendapat nilai tertinggi diantara tujuan lainnya, disebabkan Kota Bogor memiliki ikon Kebun Raya Bogor di jantung kota. Kemudian pemerintah daerah Kota Bogor gencar merenovasi ruang-ruang taman kota sebagai sarana masyarakat beraktivitas.

B. Analisis faktor komfirmatori

Analisis faktor konfirmatori (AFK) adalah suatu teknik statistik untuk menguji suatu teori hubungan pola antar indikatorindikator dari beberapa konstruksi permasalahan. Sebagaimana diterangkan oleh Bachrudin dan Tobing (2001), analisis faktor konfirmatori bertujuan untuk mengevaluasi pola-pola hubungan antara beberapa konstruk. Setiap konstruk dibangun oleh indikator-indikator. Model analisis konfirmatori biasanya tidak diasumsikan arah hubungan antar konstruk, tetapi hanya adanya hubungan korelatif antar juga model deskriptif (Ferdinand 2000) adalah operasionalisasi variabel laten atau konstruk menjadi satu atau beberapa indikator atau beberapa variabel manifes yang dirumuskan menurut kajian teori tertentu.

AFK dilakukan dengan menggunakan bantuan software AMOS, dimana seluruh tujuan dan indikator yang ada pada indeks kota ramah air akan dilihat hubungannya dan nilai korelasinya. Korelasi maksimum akan bernilai 1 (satu), dengan tanda positif sebagai penanda hubungan lurus dan nilai negatif sebagai hubungan terbalik.

Diagram AFK secara keseluruhan atas model indeks kota ramah air dapat dilihat pada Gambar 4. Model ini memberikan nilai chi-square 711 dengan derajat bebas sebesar 488 model ini memberikan tingkat kepercayaan sebesar 95\% dengan tingkat kesalahan model terhadap data sebesar 0.079. Nilai RMSEA yang lebih kecil atau sama dengan 0.08 merupakanindeks untuk dapat diterimanya model yang menunjukkan sebuah closefit dari model itu berdasarkan degrees of freedom ( Browne dan Cudeck 1993). konstruk. AFK digunakan dengan tujuan 


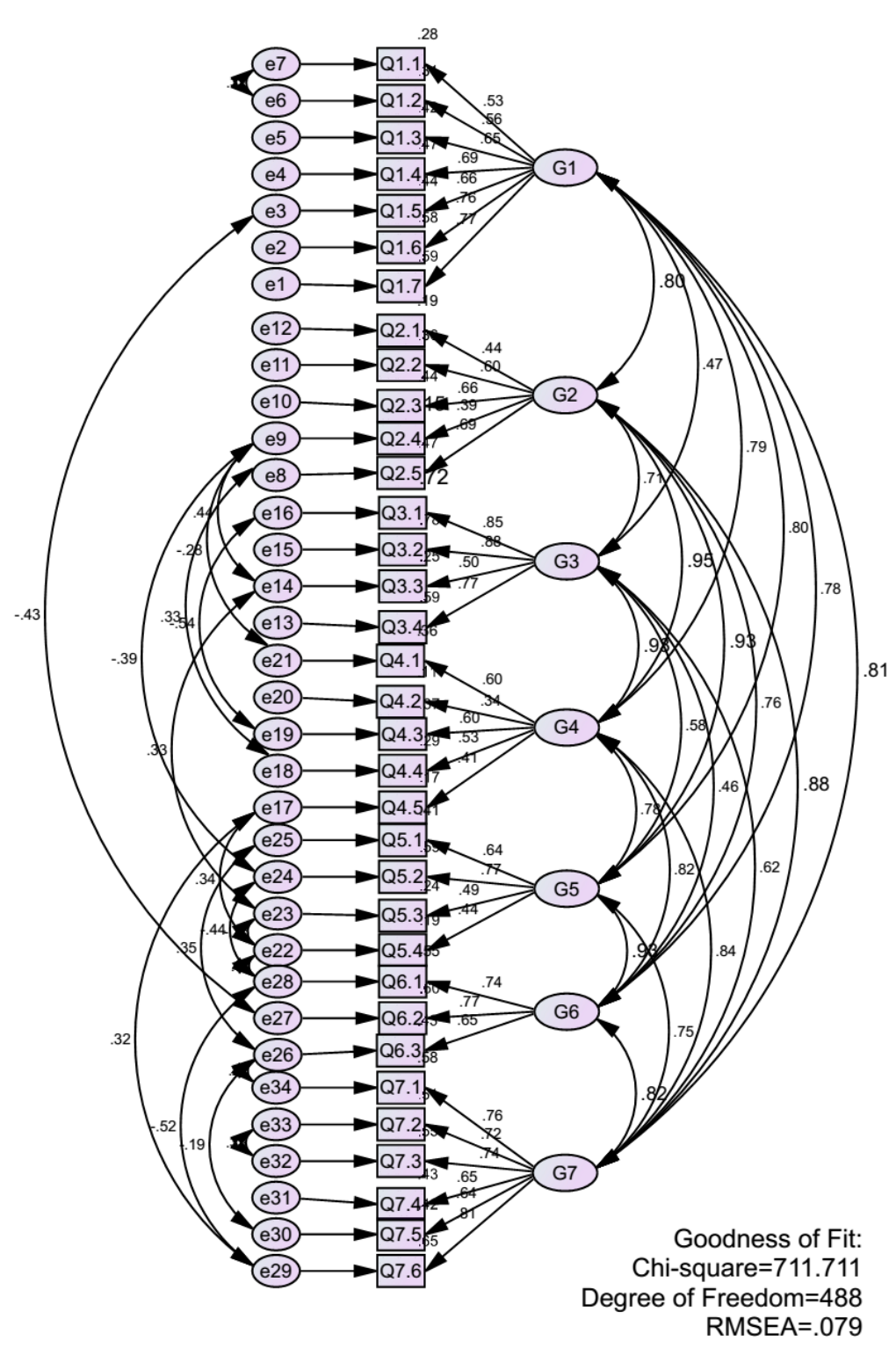

Gambar 4 Diagram AFK dari Indeks Kota Ramah Air Untuk Kota Bogor

Nilai hubungan antara tujuan meningkatkan modal sosial (G2) dengan perbaikan produktifitas dan efesiensi sumber daya (G4) memiliki nilai tertinggi sebesar 0,95. Hal dapat dikatakan bahwa dengan membangun modal sosial di Kota Bogor akan meningkatkan produktifitas dan efesiensi penggunaan sumber daya air secara signifikan. Sedangkan nilai hubungan terendah yaitu sebesar 0,46 terdapat pada hubungan antara tujuan pencapaian persamaan dari layanan dasar (G3) dengan pemastian ruang kota yang berkualitas (G6). Hal ini menunjukkan bahwa untuk kasus Kota Bogor, pemastian keberadaan ruang kota yang berkualitas berpengaruh lemah terhadap persamaan dari penerimaan layanan dasar kepada masyarakat Kota Bogor.

G1 memiliki 7 indikator yang ditanyakan pada responden. Adapun korelasi 
terbesar antara dalam indikator-indikator G1 terdapat pada indikator Q1.7. Ini menunjukkan bahwa indikator Q1.7 yaitu : Persamaan representasi dan perspektif menurut responden paling menentukan berapa skor dari tujuan G1. G2 memiliki 4 indikator yang ditanyakan pada responden. Korelasi terbesar antara dalam indikatorindikator G2 terdapat pada indikator Q2.5. Ini menunjukkan bahwa indikator Q2.5 yaitu : Keterlibatan masyarakat lokal dalam perencanaan air menurut responden paling menentukan berapa skor dari tujuan G2. G3 memiliki 4 indikator yang ditanyakan pada responden. Korelasi terbesar antara dalam indikator-indikator G3 terdapat pada indikator Q3.2. Ini menunjukkan bahwa indikator Q3.2 yaitu : Kesamaan hak akses terhadap sanitasi yang tersedia dan aman menurut responden paling menentukan berapa skor dari tujuan G3. G4 memiliki 5 indikator yang ditanyakan pada responden. Korelasi terbesar antara dalam indikatorindikator G4 terdapat pada indikator Q4.1. Ini menunjukkan bahwa indikator Q4.1 yaitu : Akses keuntungan sektor lain akibat layanan terkait air menurut responden paling menentukan berapa skor dari tujuan G4. G5 memiliki 4 indikator yang ditanyakan pada responden. Adapun korelasi terbesar antara dalam indikator-indikator G5 terdapat pada indikator Q5.2. Ini menunjukkan bahwa indikator Q5.2 yaitu : Kualitas dan aliran air permukaan menurut responden paling menentukan berapa skor dari tujuan G5. G6 memiliki 3 indikator yang ditanyakan pada responden. Korelasi terbesar antara dalam indikator-indikator G6 terdapat pada indikator Q6.2. Ini menunjukkan bahwa indikator Q6.2 yaitu : Fungsi elemen perkotaan bagi migitasi dampak pemanasan global menurut responden paling menentukan berapa skor dari tujuan G6. G7 memiliki 6 indikator yang ditanyakan pada responden. Korelasi terbesar antara dalam indikator-indikator G7 terdapat pada indikator Q7.6. Ini menunjukkan bahwa indikator Q7.6 yaitu : Perawatan yang memadai menurut responden paling menentukan berapa skor dari tujuan G7.

Berdasarkan indeks kota ramah air, Kota Bogor memiliki nilai terendah pada tujuan 2 (Peningkatan modal sosial) dan tujuan 7 (promosi infrastruktur yang adatif). Dari nilai AFK untuk tujuan 2, pertanyaan yang paling memberikan pengaruh terkuat adalah Q2.5, yaitu: keterlibatan masyarakat lokal dalam perencanaan air di Kota Bogor. Hasil nilai AFK Tujuan 7, pertanyaan yang paling kuat pengaruhnya adalah Q7.6 yaitu : perawatan infrastruktur yang memadai.

Kota Bogor memiliki nilai indeks tertinggi dalam tujuan 6 , yaitu tujuan mengenai keberadaan ruang kota yang berkualitas. Kota Bogor diuntungan oleh 
keberadaan kebun raya seluas $87 \mathrm{Ha}$ yang berada di tengah kota. Hal lain yang mendukung adalah adanya kebijakan pemerintah daerah Kota Bogor untuk memperlebar trotoar bagi pejalan kaki. Juga kebijakan untuk merevitalisasi taman-taman yang ada di Kota Bogor, seperti: taman kencana, taman heulang dan taman sempur.

Kota Bogor memiliki potensi sumberdaya air permukaan yang melimpah. Hasil simulasi dari data TRMM menunjukkan bahwa setiap tahunnya Kota
Bogor memiliki potensi air permukaan sebanyak $484.327 .589 \mathrm{~m}^{3} /$ tahun hingga 927.339.294 $\mathrm{m}^{3} /$ tahun. Apabila menggunakan standar kelayakan pemenuhan kebutuhan air perkotaan sebanyak 250 L/jiwa/hari, maka jumlah air tersebut cukup untuk memenuhi kebutuhan penduduk Kota Bogor hingga tahun 2100. Pada tahun 2100 di prediksi terdapat 3555069 jiwa yang menjadi penduduk Kota Bogor.

Air permukaan tersebut akan mengalir melalui sungai-sungai di Kota Bogor. Hasil

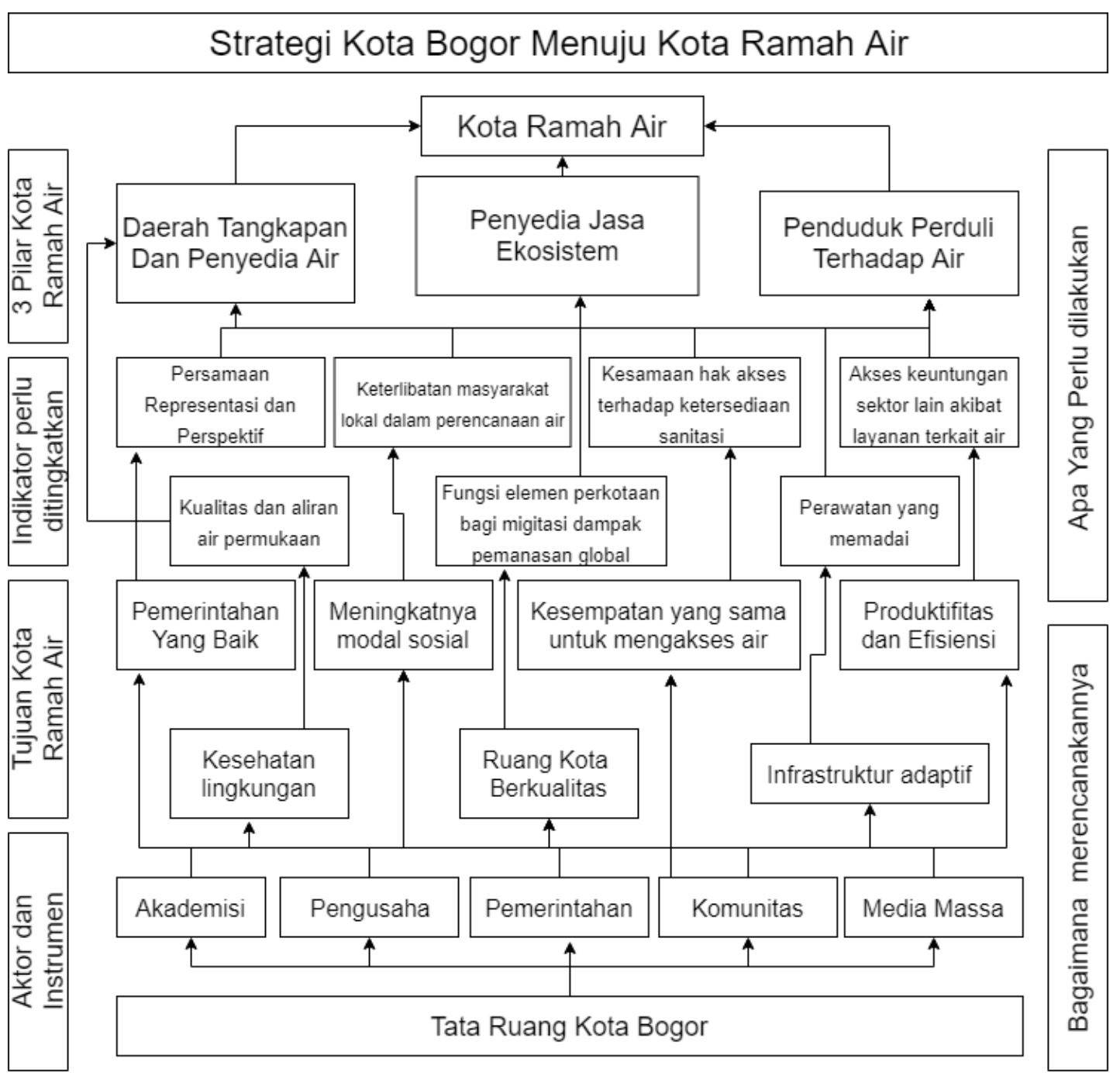

Gambar 5. Skema Strategi Kota Bogor Menuju Kota Ramah Air 
pengukuran parameter kualitas air di dua sungai utama Kota Bogor, yaitu: Sungai Ciliwung dan Sungai Cisadane, menunjukkan bahwa air yang masuk ke kawasan Kota Bogor ternyata mengalami penurunan kualitas setelah keluar dari Kota Bogor. Hal ini menunjukkan bahwa aktifitas perkotaan memberikan dampak negatif terhadap kualitas air permukaan. Sehingga Kota Bogor belum dapat disebut sebagai kota ramah air. Kota ramah air memiliki ciri bahwa kota tersebut dapat memberikan jasa lingkungan pada wilayah sekitarnya. Air permukaan yang melewati kota ramah air, minimal kualitasnya sama ketika keluar menuju area tetangganya. Peristiwa banjir pada tahun 2017 yang diakibatkan oleh curah hujan tinggi di hulu selatan Kota Bogor, serta kekeringan di musim kemarau panjang, menunjukkan bawah pengelolaan sumberdaya air di Kota ini masih belum berjalan dengan baik.

Untuk menuju kota ramah air, telah dihitung suatu indeks yang menunjukkan posisi Kota Bogor saat ini dalam proses perkembangan yang cukup baik. 74 responden menilai Kota Bogor dengan skor rata-rata 2,74 dari skor ideal 5. Dengan data yang sama dapat dihitung indikator mana yang paling dominan dalam menentukan skor akhir tiap tujuan. Sehingga dengan memperhatikan skor indikator yang dominan tersebut, diharapkan Kota Bogor dapat menjadi kota ramah air lebih cepat dan terarah.

Instrumen yang dapat digunakan sebagai dasar pengelolaan sumberdaya air permukaan di Kota Bogor adalah melalu rencana tata ruang Kota Bogor (Gambar 5). Pentabelix yang terdiri dari Akademisi, Pengusaha, Pemerintah, Komunitas dan Media massa perlu dilibatkan dalam proses perencanaan tata ruang. Tujuan kota ramah air ada 7, yaitu menciptakan pemerintahan yang baik, meningkatkan modal sosial, menciptakan kesempatan yang sama untuk mengakses air, adanya produktifitas dan efisiensi sumberdaya air, memelihara kesehatan lingkungan, menciptakan ruang kota berkualitas dan membangun infrastruktur yang adaptif.

\section{REFERENSI}

Arya B. 2017. Dua Permasalahan Transportasi dan Kemacetan [Internet]. Tersedia pada: https://kotabogor.go.id/index.php/s how_post/detail/7754/. diakses pada tanggal 29 Juli 2018.

Browne M W, Cudeck R. 1993. Alternative ways of assessing model fit. dalam Bollen, K.A. \& Long, J.S. [Eds.] Testing structural equation models. Newbury Park, CA: Sage, 136-162.

Brown R, Keath N, Wong T. 2009. Urban water management in cities: Historical, 
current and future regimes. Water Science \&

Technology, 59 (5). Melbourne: IWA Publishing.

Brown R, Rogers B, Werbeloff L. 2016. Moving toward Water Sensitive Cities: A guidance manual for strategists and policy makers. Cooperative Research Centre for Water Sensitive Cities. Melbourne. Australia.

[BAPPEDA] Badan Perencanaan Pembangunan Daerah. 2012. Strategi Sanitasi Kota Bogor 2010-2014 (Edisi Revisi 2013-2017). Pemerintah Daerah Kota Bogor.

[BPS] Badan Pusat Statistik. 2017. Kota Bogor Dalam Angka 2017, Badan Pusat Statistik, Bogor, [interet]. [diacu 26 September 2017]. Tersedia pada : http://bappeda.kotabogor.go.id/fron tend/bogorangka/2017.

Ferdinand A. 2000. Structural Equation Modelling dalam Penelitian Manajemen. Program Magister Manajemen. Semarang (ID): Universitas Diponegoro.

Hadimuljono M B. 2016. Water is a key: Let us face the future together and with confience, Indonesia The Netherlands-Partnership For Water Challenges. Magazine. Ministry of
Public Works and HousingInternational Cooperation Division. Jakarta (ID): Bureau of Budget Planning \& International Cooperation

Lloyd S, Roberts S, Beck L. 2016. Water Sensitive Cities Benchmarking and Assessment: Moonee Valley City Council Melbourne. Melbourne (AU): Cooperative Research Centre for Water Sensitive Cities.

Wong T H F, Brown R R. 2009. The water sensitive city: principles for practice. Water Science \& Technology. Melbourne-VIC (AU): IWA Publishing. 